\title{
TRANSFORMASI MODEL PELAKSANAAN PEMILIHAN KEPALA DAERAH SERENTAK
}

(The Transformation of Simultaneous Regional Election Execution Models)

\author{
Yuliyanto \\ Peneliti pada Pusat Penelitian dan Pengembangan Hukum \\ Badan Penelitian dan Pengembangan Hukum dan HAM \\ Kementerian Hukum dan HAM Republik Indonesia \\ Jalan HR. Rasuna Said Kavling 4-5, Kuningan, Jakarta Selatan 12940 \\ Telepon (021) 2525015 Faksimili (021) 2526438 \\ HP: 08121065634 - Email: yuliyanto_oke@yahoo.com \\ Tulisan Diterima: 06-02-2017; Direvisi: 16-03-2017; \\ Disetujui Diterbitkan: 22-03-2017
}

\begin{abstract}
The first phase of Simultaneous Regional Election has been concluded. However, it remains with problems and in the execution. The problem identification to be discussed in this essay is: (1) what is the fundamental changes in the simultaneous Regional Election based on Law Number 1 of 2015 in conjunction with Law Number 8 of 2015?; (2) what is the positive and negative impacts of the implementation o simultaneous regional election (Pilkada) on 9 December 2015?; and (3) what is the ideal simultaneous local election (Pilkada) as an effort to strengthen the democracy in Indonesia. This research tries to provide a policy recommendation for all the stakeholders. The research method used is qualitative, as for the type of research itself was the social-juridical approach, using document study and interview as the method of its data collection. The research provides the following recommendation: (1) Committee II in the Parliament/People Representative Council to Amend/Revise Law No. 10 of 2016 Concerning The Second Amendment to Law Number 1 of 2015 concerning Governor, Regent, and Mayor Election; (2) General Election Committee to issue a regulation on public exposure mechanism.
\end{abstract}

Keywords: Model Transformation, Simultaneous Regional Election.

\begin{abstract}
ABSTRAK
Pemilihan Kepala Daerah Serentak gelombang pertama sudah dilaksanakan, tapi masih banyak permasalahan dalam pelaksanaannya. Rumusan masalah yang akan dibahas adalah: (1) bagaimana perubahan mendasar dari pelaksanaan Pilkada serentak berdasarkan UndangUndang Nomor 1 Tahun 2015 Jo. Undang-Undang Nomor 8 tahun 2015?; (2) apa dampak positif dan negatif pelaksanaan Pilkada serentak yang telah diselenggarakan pada tanggal 9 Desember 2015?; dan (3) bagaimanakah model pelaksanaan Pilkada serentak yang ideal dalam upaya penguatan demokrasi di Indonesia. Penelitian ini diharapkan mampu memberikan rekomendasi kebijakan bagi pemangku kepentingan. Metode penelitian yang digunakan adalah kualitatif, sedangkan jenis penelitiannya adalah yuridis sosiologis, dengan teknik pengumpulan data studi dokumen dan wawancara. Dari hasil penelitian merekomendasikan hal-hal sebagai berikut: (1) Komisi II Dewan Perwakilan Rakyat agar melakukan Perubahan/Revisi Undang-Undang Nomor 10 Tahun 2016 tentang Perubahan Kedua Undang-Undang Nomor 1 Tahun 2015 Tentang Pemilihan Gubernur, Bupati dan Walikota; (2) Komisi Pemilihan Umum agar membuat peraturan mengenai mekanisme uji publik.
\end{abstract}

Kata Kunci: Transformasi Model, Pilkada Serentak. 


\section{PENDAHULUAN}

Pasal 18 ayat (4) Undang-Undang Dasar 1945 menentukan bahwa "Gubernur, Bupati dan Walikota masingmasing sebagai kepala pemerintah daerah provinsi, kabupaten dan kota dipilih secara demokratis". Pemaknaan arti kata demokratis dalam ketentuan tersebut dengan memilih mekanisme pemilihan secara langung sebagaimana diatur dalam Undang-Undang Nomor 32 Tahun 2004 tentang Pemerintahan Daerah. Pasal 24 ayat (5) menentukan bahwa kepala daerah dan wakil kepala daerah dipilih dalam satu pasangan secara langsung oleh rakyat di daerah yang bersangkutan.

Perkembangannya Pilkada di Indonesia sudah memasuki 2 periode, periode pertama adalah Pilkada yang dilaksanakan dalam rentang waktu 2005-2008 dan periode kedua yaitu Pilkada yang dilaksanakan dalam rentang waktu 20102013. Periodesasi Pilkada ini didasari pada rentang waktu 2005-2008 hanya partai politik atau gabungan partai politik saja yang boleh mengajukan calon kepala daerah dan wakil kepala daerah namun pada rentang waktu 2010-2013 sejak keluarnya Keputusan Mahkamah Konstitusi Nomor 5/PUU-V/2007 yang kemudian ditindaklanjuti dengan UndangUndang Nomor 12 Tahun 2008 Tentang Perubahan Kedua Undang-Undang Nomor 32 Tahun 2004 yang mengatur tentang calon perseorangan, setelah itu baru diperbolehkan calon perseorangan ikut dalam kontestasi Pilkada.

Jika dikaitkan dengan konsep negara hukum, menurut Aristoteles (384-322 S.M) adalah negara yang berdiri diatas hukum yang menjamin keadilan kepada warga negaranya. Keadilan merupakan syarat bagi tercapainya kebahagian hidup untuk warga negaranya, dan sebagai dasar dari pada keadilan itu perlu diajarkan rasa susila kepada setiap manusia agar ia menjadi warga negara yang baik. Bagi Aristoteles yang memerintah dalam negara bukanlah manusia sebenarnya, melainkan pikiran yang adil, sedangkan penguasa sebenarnya hanya pemegang hukum dan keseimbangan saja. Sedangkan negara demokrasi adalah negara yang diselenggarakan berdasarkan kehendak dan kemauan rakyat, atau, jika ditinjau dari sudut organisasi, ia berarti suatu pengorganisasian negara yang dilakukan oleh rakyat karena kedaulatan berada di tangan rakyat. Apabila ditinjau dari arti katanya, maka hal itu tidak mungkin diwujudkan, karena mustahil orang yang berjumlah lebih banyak memerintah orang yang lebih sedikit. Hal ini yang dinamakan demokrasi formil atau demokrasi menurut bentuknya. Disamping demokrasi formil, terdapat pula demokrasi dari segi isinya atau materinya. Proses perjalanan demokrasi di Indonesia mengalami kemajuan, hal ini ditandai dengan pelaksanaan pemilihan kepala daerah yang langsung dipilih oleh rakyat, meskipun dalam perjalanannya masih banyak kekurangan atau permasalahan.

Berdasarkan catatan Perkumpulan Untuk Pemilu dan Demokrasi (Perludem) tercatat setidaknya terdapat 5 (lima) permasalahan yang terjadi dalam Pilkada pada periode pertama maupun periode kedua (Tim Peneliti Perludem, 2011: vivii). Permasalahan tersebut meliputi, pertama, permasalahan dari kerangka hukum yang masih menyisakan berbagai kesimpangsiuran maupun ketidakjelasan bagi penyelenggara, peserta, maupun pemilih dalam pemaknaannya, yang tidak jarang berakibat pada konflik dan gangguan keamanan. Aturan yang ambigu dan multitafsir yang pada akhirnya berkontribusi pada rentetan persoalan dalam menyelenggarakan tahapan Pilkada, misalnya masalah carut marutnya daftar pemilih, kisruh pencalonan, kampanye yang tidak terkontrol, sampai pemungutan dan penghitungan suara yang bermasalah. 
Kedua, masalah sistem pemilihan dan metode pencalonan. Sistem pencalonan memberikan ruang bagi partai politik, gabungan partai politik, dan calon perseorangan untuk memajukan calon, melahirkan begitu banyak kandidat yang kemudian diikuti dengan permasalahan berikut biaya penyelenggaraan yang mahal dan politik biaya tinggi (atau politik uang). Selain itu ruang bagi parpol non-kursi di DPRD untuk mencalonkan kandidat, sepanjang memperoleh $15 \%$ suara sah dalam Pemilu Legislatif yang lebih banyak membawa masalah ketimbang manfaat bagi Pilkada. Diantaranya melahirkan banyak dukungan ganda dalam pencalonan, dan maraknya politik transaksional jual beli dukungan. Ketiga, masalah dalam penyelenggaraan tahapan yang diakibatkan oleh ketidaksiapan penyelenggara, kematangan kandidat, maupun akseptabilitas pemilih atas proses penyelenggaraan tahapan yang ada. Di tingkat lapangan masih ditemui banyak penyelenggara yang tidak profesional dan mumpuni dalam menyelenggarakan Pilkada (walau harus diakui hal ini juga terjadi karena adanya kontribusi dari kerangka hukum yang bermasalah tersebut). Selain itu, penyelenggaraan Pilkada biasanya tidak bermasalah (atau tidak dipermasalahkan) pada tahapantahapan awalnya, sampai kemudian diketahui hasil penghitungan suara. Barulah para kandidat dan masa pendukungnya beraksi melakukan protes dan penolakan yang tidak jarang berakhir pada kerusuhan dan konflik horizontal antar masyarakat.

Keempat, masalah penegakan hukum dan penanganan pelanggaran. Aturan yang ada belum bisa merespon persoalan riel dan kompleks yang terjadi di lapangan. Ketentuan hukum acara penanganan pelanggaran Pilkada diatur secara belum terperinci dalam undang-undang yang ada (dan ujungnya lagi-lagi menyebabkan kebingungan dalam penerapannya di lapangan). Kapasitas penegak hukum pun banyak menyisakan bahkan menimbulkan masalah baru. Hal ini bisa dipahami karena masih minimnya program untuk peningkatan pemahaman dan kapasitas dalam menangani berbagai pelanggaran Pilkada. Kelima, tersebarnya waktu penyelenggaraan Pilkada melahirkan kompleksitas dalam pelaksanaannya yang pada akhirnya juga berujung pada pembengkakan dan pemborosan anggaran. Bahkan muncul fakta sampai ada daerah yang mengambil anggaran pendidikan dan kesehatannya untuk memenuhi alokasi anggaran penyelenggaraan Pilkada. Pemilih juga akhirnya bosan dan kehabisan energi karena terus-terusan harus 'ber-Pemilu-ria". Tidak mengherankan jika dari Pemilu Legislatif ke Pemilu Presiden sampai ke Pilkada grafik partisipasi pemilih terus menurun.

Namun sangat disayangkan, pada tahun 2014 dalam sejarah perpolitikan di Indonesia, khususnya di dalam pelaksanaan Pilkada, Dewan Perwakilan Rakyat (DPR) bukannya memperbaiki dan menata permasalahan-permasalahan yang terjadi malahan mengembalikan sistem Pemilihan kepala daerah dan wakil kepala daerah dari Pilkada langsung menjadi pemilihan tidak langsung, yaitu dengan diterbitkannya Undang-Undang Nomor 22 tahun 2014 tentang Pemilihan Gubernur, Bupati dan Walikota. Pada Pasal 3 ayat (1) menyebutkan, Gubernur dipilih oleh anggota DPRD Provinsi secara demokratis berdasar asas bebas, terbuka, jujur, dan adil. Ayat (2) menyebutkan, Bupati dan Walikota dipilih oleh anggota DPRD kabupaten/kota secara demokratis berdasar asas bebas, terbuka, jujur, dan adil.

Belum sempat Undang-Undang Nomor 22 Tahun 2014 tersebut diimplementasikan, Presiden Susilo Bambang Yudhoyono pada tanggal 2 Oktober 2014 mengeluarkan Peraturan Pemerintah Pengganti Undang-Undang Nomor 1 tahun 2014, dimana dalam Pasal 205 menyatakan Undang-Undang Nomor 22 Tahun 2014 tentang pemilihan Gubernur, Bupati dan Walikota dicabut dan dinyatakan tidak berlaku. Pertimbangan Presiden Susilo Bambang Yudhoyono mengeluarkan Peraturan 
Pemerintah Pengganti Undang-Undang Nomor 1 Tahun 2014 yaitu UndangUndang Nomor 22 Tahun 2014 tentang Pemilihan Gubernur, Bupati, dan Walikota yang mengatur mekanisme pemilihan kepala daerah secara tidak langsung melalui Dewan Perwakilan Rakyat Daerah telah mendapatkan penolakan yang luas oleh rakyat dan proses pengambilan keputusannya telah menimbulkan persoalan serta kegentingan yang memaksa sesuai Putusan Mahkamah Konstitusi Nomor 138/PUU-VII/2009. Peraturan Pemerintah Nomor 1 Tahun 2014 mengembalikan mekanisme pemilihan kepala daerah baik gubernur, bupati dan walikota kembali secara langsung dipilih oleh rakyat, yang kemudian oleh DPR ditetapkan menjadi Undang-Undang dengan Undang-Undang Nomor 1 tahun 2015 Tentang Penetapan Peraturan Pemerintah Pengganti UndangUndang Nomor 1 tahun 2014 tentang Pemilihan Gubernur, Bupati dan Walikota menjadi Undang-Undang.

Hal menarik yang diatur didalam Undang-Undang Nomor 1 tahun 2015 adalah adanya ketentuan yang mengatur tentang Pilkada serentak yaitu di dalam pasal 3 ayat (1) Pemilihan dilaksanakan setiap 5 (lima) tahun sekali secara serentak di seluruh wilayah Negara Kesatuan Republik Indonesia. Pelaksanaan Pilkada serentak memiliki beberapa tujuan. Pertama, terciptanya efektivitas dan efisiensi anggaran. Kedua, memperkuat demokrasi di tingkat lokal yang diharapkan akan melahirkan pemerintahan daerah yang mampu menciptakan akuntabilitas di daerahnya. Ketiga, meningkatkan partisipasi rakyat yang selama ini dirasakan menurun didalam setiap pelaksanaan Pilkada, keempat, langkah awal untuk menata pelaksanaan pemilu serentak baik pemilu tingkat nasional maupun pemilu tingkat daerah. Beberapa masalah terkait Pilkada serentak sebagai berikut: (1) Terdapat perubahan mendasar pelaksanaan Pilkada serentak yang dahulunya didasarkan pada UndangUndang Nomor 32 tahun 2004 menjadi
Undang-Undang Nomor 1 Tahun 2015 Jo. Undang-Undang Nomor 8 tahun 2015; (2) Tingkat partisipasi pemilih dalam pilkada selalu mengalami trend penurunan. (3) Pelaksanaan Pilkada yang terpisah dianggap tidak efisien dari segi pembiayaan dan tidak efektif terhadap birokrasi di daerah; (4) Timbulnya dampak positif dan negatif pelaksanaan Pilkada serentak tahap pertama yang telah diselenggarakan pada tanggal 9 Desember 2015; (5) Pilkada serentak rentan terhadap gangguan keamanan yang lebih besar di daerah dibandingkan dengan Pilkada tidak serentak; dan (6) Belum terdapatnya model pelaksanaan Pilkada serentak yang ideal dalam upaya penguatan demokrasi di Indonesia.

Dalam melakukan penataan terhadap pelaksanaan Pilkada serentak yang rencananya akan dilaksanakan melalui tiga tahapan, yaitu tahap pertama akan dilaksanakan pada tanggal 9 Desember 2015 untuk kepala daerah dan wakil kepala daerah yang memasuki akhir masa jabatan 2015 dan semester pertama 2016. Tahap kedua dilakukan pada tahun 2017 untuk akhir masa jabatan semester kedua 2016 dan 2017 serta tahap ketiga dilaksanakan Juni 2018 untuk akhir masa jabatan 2018 dan 2019. Dalam Upaya melakukan penyempurnaan terhadap pelaksanaan Pilkada serentak, pemerintah juga mengeluarkan Undang-Undang Nomor 8 Tahun 2015 tentang Perubahan Atas Undang-Undang Nomor 1 tahun 2015 Tentang Penetapan Peraturan Pemerintah Pengganti Undang-Undang Nomor 1 Tahun 2014 Tentang Pemilihan Gubernur, Bupati dan Walikota menjadi Undang-Undang.

Banyak hal yang berubah dalam pelaksanaan Pilkada serentak yang tahap pertama yang dilaksanakan pada tanggal 9 Desember 2015 dan diikuti oleh 9 provinsi, 260 kabupaten/kota didasarkan pada Undang-undang Nomor 1 tahun 2015 jo Undang-Undang Nomor 8 tahun 2015 dibandingkan dengan Pilkada yang berdasarkan Undang-Undang Nomor 32 Tahun 2004 Tentang Pemerintahan 
Daerah. Pada hakekatnya Pilkada serentak dilandasi oleh tujuan penataan, pembenahan dan penyempurnaan Pilkada secara langsung namun didalam tataran implementasi masih banyak menimbulkan permasalahan dan memerlukan perbaikan dan pembenahan agar pelaksanaan Pilkada serentak tahap kedua yang rencananya akan dilaksanakan pada tahun 2017 akan lebih baik lagi dibandingkan pelaksanaan Pilkada serentak yang dilaksanakan pada tanggal 9 Desember 2015.

Berdasarkan latar belakang masalah yang telah diuraikan di atas, maka dapat dirumuskan masalah dalam penelitian ini, yaitu: (1) Bagaimana perubahan mendasar dari pelaksanaan Pilkada serentak berdasarkan Undang-Undang Nomor 1 Tahun 2015 Jo. Undang-Undang Nomor 8 tahun 2015?; (2) Apa dampak positif dan negatif pelaksanaan Pilkada serentak yang telah diselenggarakan pada tanggal 9 Desember 2015?; dan (3) Bagaimanakah model pelaksanaan Pilkada serentak yang ideal dalam upaya penguatan demokrasi di Indonesia?.

Tujuan dari penelitian ini untuk (1) mengetahui dan menganalisis perubahan mendasar dari pelaksanaan Pilkada serentak berdasarkan Undang-Undang Nomor 1 tahun 2015 jo. Undang-Undang Nomor 8 tahun 2015; (2) mengetahui dan menganalisis dampak positif dan negatif pelaksanaan Pilkada serentak yang telah diselenggarakan pada tanggal 9 Desember 2015; dan (3) merumuskan model pelaksanaan Pilkada serentak yang ideal dalam upaya penguatan demokrasi di Indonesia.

Sedangkan manfaat dari penelitian ini terciptanya rekomendasi kebijakan yang ditujukan kepada DPR dan Komisi Pemilihan Umum (KPU) untuk merumuskan peraturan baik dalam bentuk Undang-Undang, Peraturan Pemerintah ataupun Peraturan Komisi Pemilihan Umum terkait dengan model Pilkada serentak dalam upaya perbaikan dan penyempurnaan pelaksanaan Pilkada serentak ditahap kedua (tahun 2017) dan tahap ketiga (2018) sehingga dapat menunjang penguatan demokrasi di Indonesia.

Metode penelitian yang digunakan adalah kualitatif. Jenis penelitiannya adalah yuridis sosiologis. Oleh karena itu, penelitian ini terdiri dari gabungan dua tahapan pelaksanaan, yaitu: (a) tahap pertama adalah penelitian terhadap hukum normatif yang berlaku; (b) tahap kedua adalah penelitian terhadap peristiwa in concreto guna mencapai tujuan yang telah ditentukan. Sifat penelitian ini deskriptif analitik bertujuan untuk mengungkapkan suatu masalah atau keadaan atau peristiwa sebagaimana adanya sehingga dapat mengungkapkan fakta yang sebenarnya (Hadari Nawawi, 1993). Lokasi penelitian ini adalahDKI Jakarta, Surabaya dan Batam, sedangkan metode pengumpulan data yang digunakan adalah: (a) studi dokumen dengan menelusuri dan mempelajari peraturan perundangundangan, buku dan litelatur, jurnal, artikel baik cetak maupun online serta bahan-bahan lain yang terkait dengan penelitian (Suharsimi Arikunto, 1998: 202). (b) interview (wawancara) yaitu metode pengumpulan data dengan melakukan tanya jawab (Winarno Surahmat, 1980: 17). Data yang telah terkumpul kemudian dianalisis secara kualitatif.

\section{PEMBAHASAN}

\section{Perubahan Mendasar Pelaksanaan Pilkada Serentak}

Perubahan pelaksanaan pemilihan kepala daerah di dalam Undang-Undang Nomor 32 tahun 2004 dan UndangUndang Nomor 1 tahun 2015 Jo. UndangUndang Nomor 8 tahun 2015 dapat dilihat di dalam tabel berikut ini: 


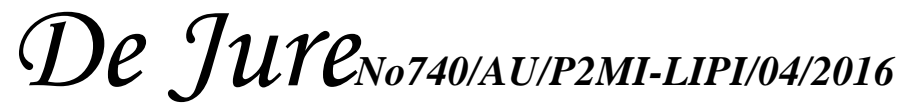

\begin{tabular}{|c|c|c|c|}
\hline $\begin{array}{l}\text { Perubahan } \\
\text { Mendasar }\end{array}$ & $\begin{array}{c}\text { Undang-Undang } \\
\text { Nomor } 32 \text { Tahun } \\
2004\end{array}$ & $\begin{array}{c}\text { Undang-Undang Nomor } \\
1 \text { Jo Nomor } 8 \text { Tahun } \\
2015\end{array}$ & $\begin{array}{c}\text { Undang- } \\
\text { Undang } \\
\text { Nomor } 10 \text { Tahun } \\
\mathbf{2 0 1 6}\end{array}$ \\
\hline $\begin{array}{l}\text { Waktu } \\
\text { Pelaksanaan }\end{array}$ & $\begin{array}{l}\text { Disesuaikan dengan } \\
\text { masa habis jabatan } \\
\text { kepala Daerah. } \\
\text { Berdasatkan Pasal } 65 \\
\text { "Pemilihan kepala } \\
\text { daerah dan wakil } \\
\text { kepala daerah } \\
\text { dilaksanakan melalui } \\
\text { masa persiapan dan } \\
\text { tahapan pelaksanaan } \\
\text { (ayat 1). Lebih lanjut } \\
\text { didalam ayat (2) diatur } \\
\text { masa persiapan } \\
\text { sebagaimana dimaksud } \\
\text { ayat 1 meliputi: } \\
\text { a. Pemberitahuan } \\
\text { DPRD kepada } \\
\text { kepala daerah } \\
\text { mengenai } \\
\text { berakhirnya masa } \\
\text { jabatan; } \\
\text { b. Pemberitahuan } \\
\text { DPRD kepada } \\
\text { KPUD mengenai } \\
\text { berakhirnya masa } \\
\text { jabatan kepala } \\
\text { daerah; } \\
\text { c. Perencanaan } \\
\text { penyelenggaraan, } \\
\text { meliputi penetapan } \\
\text { tata cara dan jadwal } \\
\text { tahapan pelaksanaan } \\
\text { pemilihan kepala } \\
\text { daerah; Pan; } \\
\text { d. Pembentukan } \\
\text { Panitia Pengawas, } \\
\text { PPK, PPS dan } \\
\text { KPPS; } \\
\text { e. Pemberitahuan dan } \\
\text { pendaftaran } \\
\text { pemantau. }\end{array}$ & $\begin{array}{l}\text { Pasal } 3 \text { (1) Pemilihan } \\
\text { dilaksanakan setiap } 5 \\
\text { (lima) tahun sekali secara } \\
\text { serentak di seluruh } \\
\text { wilayah Negara Kesatuan } \\
\text { Republik Indonesia. }\end{array}$ & $\begin{array}{ll}\text { Tidak } & \text { ada } \\
\text { perubahan. } & \end{array}$ \\
\hline $\begin{array}{l}\text { Institusi } \\
\text { Penyelenggara }\end{array}$ & $\begin{array}{lr}\text { KPUD } & \text { yang } \\
\text { bertanggung } & \text { Jawab } \\
\text { Kepada DPRD } & \\
\text { Pasa1 57 (1) Pemilihan } \\
\text { kepala daerah dan }\end{array}$ & $\begin{array}{l}\begin{array}{l}\text { KPUD dan } \\
\text { sebagai }\end{array} \text { penanggung } \\
\text { jawab akhir } \\
\text { Pasal 6 (1) KPU Provinsi } \\
\text { menyampaikan laporan }\end{array}$ & $\begin{array}{l}\text { Tidak } \\
\text { perubahan. }\end{array}$ \\
\hline
\end{tabular}




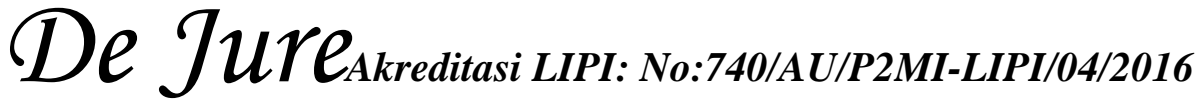

\begin{tabular}{|c|c|c|c|}
\hline $\begin{array}{l}\text { Perubahan } \\
\text { Mendasar }\end{array}$ & $\begin{array}{c}\text { Undang-Undang } \\
\text { Nomor } 32 \text { Tahun } \\
2004\end{array}$ & $\begin{array}{c}\text { Undang-Undang Nomor } \\
1 \text { Jo Nomor } 8 \text { Tahun } \\
2015\end{array}$ & $\begin{array}{c}\text { Undang- } \\
\text { Undang } \\
\text { Nomor } 10 \text { Tahun } \\
2016\end{array}$ \\
\hline & $\begin{array}{l}\text { wakil kepala daerah } \\
\text { diselenggarakan oleh } \\
\text { KPUD yang } \\
\text { bertanggungjawab } \\
\text { kepada DPRD. } \\
\text { (2) Dalam } \\
\text { melaksanakan } \\
\text { tugasnya, KPUD } \\
\text { menyampaikan laporan } \\
\text { penyelenggaraan } \\
\text { pemilihan kepala } \\
\text { daerah dan wakil } \\
\text { kepala daerah kepada } \\
\text { DPRD. }\end{array}$ & $\begin{array}{l}\text { kegiatan setiap tahapan } \\
\text { penyelenggaraan } \\
\text { Pemilihan Gubernur dan } \\
\text { Wakil Gubernur kepada } \\
\text { DPRD Provinsi dan KPU } \\
\text { dengan tembusan kepada } \\
\text { Presiden melalui Menteri. } \\
\text { (2) KPU Kabupaten/Kota } \\
\text { menyampaikan laporan } \\
\text { kegiatan setiap tahapan } \\
\text { penyelenggaraan } \\
\text { Pemilihan Bupati dan } \\
\text { Wakil Bupati serta } \\
\text { Pemilihan Walikota dan } \\
\text { Wakil Walikota kepada } \\
\text { DPRD Kabupaten/Kota } \\
\text { dengan tembusan kepada } \\
\text { KPU Provinsi dan } \\
\text { Gubernur. }\end{array}$ & \\
\hline \multirow[t]{3}{*}{$\begin{array}{l}\text { Syarat Calon } \\
\text { dan } \\
\text { Pencalonan }\end{array}$} & $\begin{array}{lrr}\text { Pasal } 58 & \text { huruf } & \text { h } \\
\text { "Mengenal } & \text { daerahnya } \\
\text { dan dikenal } & \text { oleh } \\
\text { masyarakat } & & \text { di } \\
\text { daerahnya. } & & \end{array}$ & 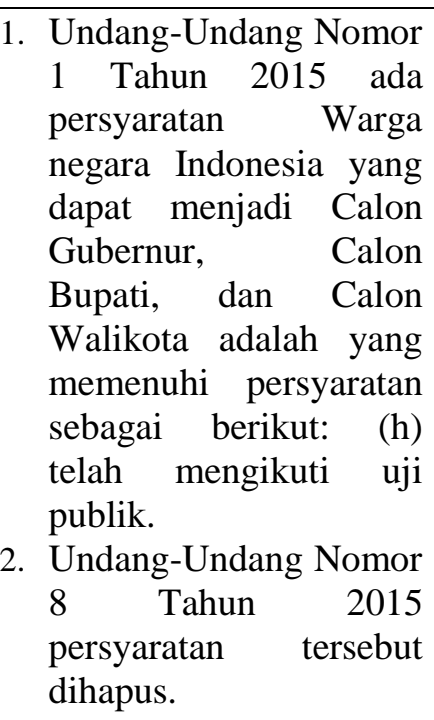 & $\begin{array}{l}\text { Tidak ada } \\
\text { perubahan. }\end{array}$ \\
\hline & $\begin{array}{l}\text { Tidak ada aturan } \\
\text { tersebut. }\end{array}$ & $\begin{array}{ll}\text { Pasal } 7 \text { poin }(\mathrm{r}) & \\
\text { tidak memiliki } & \text { konflik } \\
\text { kepentingan } & \text { dengan } \\
\text { petahana. } & \end{array}$ & Dihapus. \\
\hline & $\begin{array}{lr}\text { Pasal } 59 & \text { ayat (5) } \\
\text { point(g) } & \text { Kesediaan } \\
\text { untuk mengundurkan } \\
\text { diri dari jabatan negeri } \\
\text { bagi calon }\end{array}$ & $\begin{array}{lrr}\text { Pasal } 7 & \text { poin } & (\mathrm{t}) \\
\text { mengundurkan } & \text { diri } \\
\text { sebagai anggota } & \text { Tentara } \\
\text { Nasional } & \text { Indonesia, } \\
\text { Kepolisian } & \text { Negara }\end{array}$ & $\begin{array}{l}\text { Pasal } 7 \text { point }(\mathrm{t}) \\
\text { mengundurkan diri } \\
\text { sebagai anggota } \\
\text { Tentara Nasional } \\
\text { Indoneia, }\end{array}$ \\
\hline
\end{tabular}




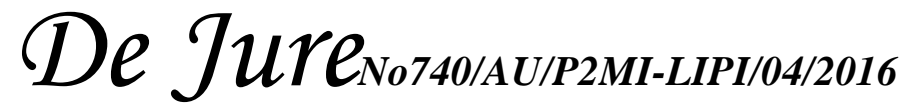

\begin{tabular}{|c|c|c|c|}
\hline $\begin{array}{l}\text { Perubahan } \\
\text { Mendasar }\end{array}$ & $\begin{array}{c}\text { Undang-Undang } \\
\text { Nomor } 32 \text { Tahun } \\
2004\end{array}$ & $\begin{array}{c}\text { Undang-Undang Nomor } \\
1 \text { Jo Nomor } 8 \text { Tahun } \\
2015\end{array}$ & $\begin{array}{c}\text { Undang- } \\
\text { Undang } \\
\text { Nomor } 10 \text { Tahun } \\
2016\end{array}$ \\
\hline & $\begin{array}{lr}\text { yang berasal } & \text { dari } \\
\text { pegawai } & \text { negeri } \\
\text { anggota } & \text { Tentara } \\
\text { Nasional } & \text { Indonesia, } \\
\text { dan anggota } & \text { Kepolisian } \\
\text { Negara } & \text { Republik } \\
\text { Indonesia. } & \\
\end{array}$ & $\begin{array}{l}\text { Republik Indonesia, dan } \\
\text { Pegawai Negeri Sipil } \\
\text { sejak mendaftarkan diri } \\
\text { sebagai calon. }\end{array}$ & $\begin{array}{lr}\text { Kepolisian } & \text { Negara } \\
\text { Republik Indonesia } \\
\text { dan Pegawai } \\
\text { Negeri Sipil sejak } \\
\text { ditetapkan sebagai } \\
\text { pasangan calon } \\
\text { pemilihan. }\end{array}$ \\
\hline & $\begin{array}{l}\text { Tidak ada aturan } \\
\text { tersebut. }\end{array}$ & $\begin{array}{l}\text { Pasal } 7 \text { poin }(\mathrm{u}) \text { berhenti } \\
\text { dari jabatan pada badan } \\
\text { usaha milik negara atau } \\
\text { badan usaha milik daerah } \\
\text { sejak ditetapkan sebagai } \\
\text { calon. }\end{array}$ & $\begin{array}{l}\text { Tidak ada } \\
\text { perubahan. }\end{array}$ \\
\hline & $\begin{array}{l}\text { Pasal } 59 \text { ayat (5) Partai } \\
\text { politik atau gabungan } \\
\text { partai politik pada saat } \\
\text { mendaftarkan pasangan } \\
\text { calon, wajib } \\
\text { menyerahkan: } \\
\text { 1) surat pencalonan } \\
\text { yang ditandatangani } \\
\text { oleh pimpinan partai } \\
\text { politik } \\
\text { atau pimpinan partai } \\
\text { politik yang } \\
\text { bergabung; }\end{array}$ & 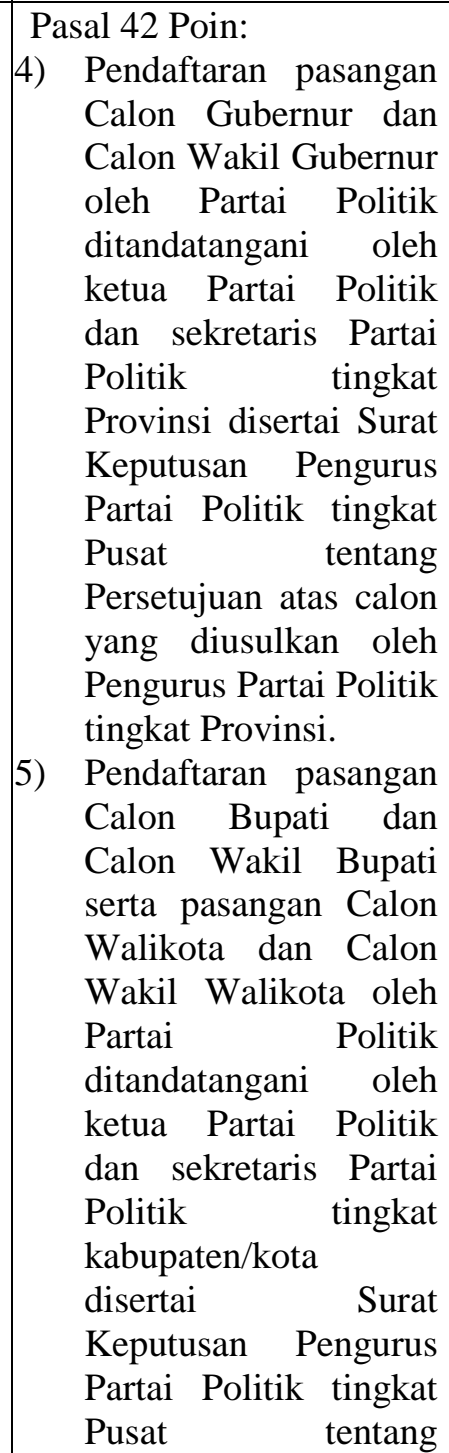 & $\begin{array}{ll}\text { Tidak } & \text { ada } \\
\text { perubahan. }\end{array}$ \\
\hline
\end{tabular}




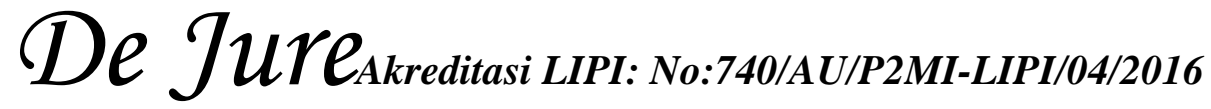

\begin{tabular}{|c|c|c|c|}
\hline $\begin{array}{l}\text { Perubahan } \\
\text { Mendasar }\end{array}$ & $\begin{array}{c}\text { Undang-Undang } \\
\text { Nomor } 32 \text { Tahun } \\
2004\end{array}$ & $\begin{array}{c}\text { Undang-Undang Nomor } \\
1 \text { Jo Nomor } 8 \text { Tahun } \\
2015\end{array}$ & $\begin{array}{c}\text { Undang- } \\
\text { Undang } \\
\text { Nomor } 10 \text { Tahun } \\
2016\end{array}$ \\
\hline & & $\begin{array}{l}\text { Persetujuan atas calon } \\
\text { yang diusulkan oleh } \\
\text { Pengurus Partai Politik } \\
\text { tingkat Provinsi. }\end{array}$ & \\
\hline & \begin{tabular}{lr}
\multicolumn{2}{l}{ Tahapan kampanye } \\
yang dibiayai & KPUD \\
hanya & debat \\
publik/debat terbuka & tebar pasangan calon. \\
antar pal
\end{tabular} & $\begin{array}{l}\text { Pasal } 65 \text { ayat }(2) \\
\text { Kampanye sebagaimana } \\
\text { dimaksud pada ayat (1) } \\
\text { huruf c } \text { (debat } \\
\text { publik/debat terbuka antar } \\
\text { pasangan, huruf d } \\
\text { (Penyebaran } \\
\text { kampanye kepada umum, } \\
\text { huruf e (Pemasangan alat } \\
\text { peraga) dan huruf f (iklan } \\
\text { massa cetak dan media } \\
\text { massa } \\
\text { difasilitasi olektronik) } \\
\text { Provinsi KPU } \\
\text { Kabupaten/Kota } \\
\text { didanai APBD. }\end{array}$ & $\begin{array}{ll}\text { Tidak ada } \\
\text { perubahan. }\end{array}$ \\
\hline $\begin{array}{l}\text { Penetapan } \\
\text { Kepala } \\
\text { Daerah } \\
\text { terpilih }\end{array}$ & $\begin{array}{l}\text { Pasal } 107 \text { ayat }(1) \\
\text { Pasangan calon kepala } \\
\text { daerah dan wakil } \\
\text { kepala daerah yang } \\
\text { memperoleh } \\
\text { lebih dari } 50 \% \text { (lima } \\
\text { puluh persen) jumlah } \\
\text { suara sah ditetapkan } \\
\text { sebagai pasangan calon } \\
\text { terpilih. }\end{array}$ & $\begin{array}{l}\text { 1. Pasal } 107 \text { ayat (1) } \\
\text { Pasangan calon bupati } \\
\text { dan calon wakil bupati } \\
\text { serta pasangan calon } \\
\text { walikota dan calon } \\
\text { wakil walikora yang } \\
\text { memperoleh suara } \\
\text { terbanyak ditetapkan } \\
\text { sebagai pasangan } \\
\text { calon bupati dan calon } \\
\text { wakil bupati terpilih } \\
\text { serta pasangan } \\
\text { walikota dan calon } \\
\text { wakil walikota } \\
\text { terpilih; } \\
\text { 2. Pasal 109 ayat (1) } \\
\text { Pasangan calon } \\
\text { Gubernur dan wakil } \\
\text { Gubernur yang } \\
\text { memperoleh suara } \\
\text { terbanyak ditetapkan } \\
\text { sebagai pasangan } \\
\text { calon gubernur dan } \\
\text { wakil gubernur } \\
\text { terpilih. }\end{array}$ & $\begin{array}{ll}\text { Tidak ada } \\
\text { perubahan. }\end{array}$ \\
\hline
\end{tabular}

Matrik diolah berdasarkan hasil penelitian. 
Jika ditelaah, 5 (lima) perubahan pelaksanaan Pilkada pasca terbitnya Undang-Undang Nomor 8 Tahun 2015, dapat digolongkan kedalam 2 (dua)

kategori. Pertama, perubahan yang mengarah kepada hal positif dalam rangka penguatan demokrasi di Indonesia. Kedua, perubahan yang mengarah pada hal negatif terhadap demokrasi di Indonesia.

Adapun perubahan-perubahan yang mengarah kepada hal positif dalam rangka penguatan demokrasi di Indonesia, yaitu :pertama, pelaksanaan Pilkada yang serentak dilaksanakan setiap 5 (lima) tahun sekali. Terdapat beberapa tujuan yang ingin dicapai dalam pelaksanaan Pilkada serentak, yaitu, (1), terciptanya efektivitas dan efisiensi anggaran. (2) memperkuat demokrasi di tingkat lokal yang diharapkan akan melahirkan pemerintahan daerah yang mampu menciptakan akuntabilitas di daerahnya.(3) meningkatkan partisipasi rakyat yang selama ini dirasakan menurun didalam setiap pelaksanaan Pilkada, (4) keempat, langkah awal untuk menata pelaksanaan pemilu serentak baik pemilu tingkat nasional maupun pemilu tingkat daerah.

Kedua, pertanggungjawaban Komisi Pemilihan Umum Provinsi/Kabupaten/Kota tidak lagi kepada Dewan Perwakilan rakyat Daerah tetapi kepada Komisi Pemilihan Umum Pusat membawa konsekuensi bahwa Pilkada bukan lagi bagian dari pemerintah daerah tetapi bagian dari Pemilihan Umum. Hal ini menyangkut kredibilitas, kemandirian dan objektivitas kinerja Komisi Pemilihan Umum Provinsi/Kabupaten/Kota sebagai lembaga yang berkewajiban menyelenggarakan Pilkada sehingga kemungkinan intervensi dari Dewan Perwakilan Rakyat Daerah tidak perlu dikhawatirkan lagi.

Ketiga, ketentuan menyatakan secara tertulis pengunduran diri sebagai anggota Tentara Nasional Indonesia (TNI), Kepolisian Negara Republik Indonesia (POLRI), dan Pegawai Negeri Sipil (PNS) serta Kepala Desa atau sebutan lain sejak ditetapkan sebagai pasangan calon peserta
Pemilihan. Hal ini dimaksudkan agar menjaga netralitas anggota TNI, Polri dan Aparatur Sipil Negara sebagaimana diatur dalam peraturan perundang-undangan. Peraturan Pemerintah Nomor 53 Tahun 2010 Tentang Disiplin PNS menyatakan bahwa setiap PNS harus menjaga netralitas dalam Pemilu, seperti tidak boleh menjadi tim sukses, tim kampanye, atau hanya ucapan dukungan terhadap calon kepala daerah yang akan ikut dalam pemilihan kepala daerah (Pasal 4 mengenai larangan PNS). TNI, di dalam Undang-Undang Nomor 34 tahun 2004 Tentang TNI, pasal 5 disebutkan bahwa "TNI berperan sebagai alat negara di bidang pertahanan yang dalam menjalankan tugasnya berdasarkan kebijakan dan keputusan politik negara". Konsekuensi logisnya, TNI dituntut untuk tidak melibatkan diri pada kegiatan politik praktis. Salah satu aktualisasinya TNI harus bersikap netral dalam setiap kegiatan pesta demokrasi (Pemilu). Polri, berdasarkan UndangUndang Nomor 2 Tahun 2002 Tentang POLRI pasal 28 yang menjelaskan sebagai berikut: pertama, Kepolisian Negara Republik Indonesia bersikap netral dalam kehidupan politik dan tidak melibatkan diri pada kegiatan politik praktis; kedua, Anggota Kepolisian Negara Republik Indonesia tidak menggunakan hak memilih dan dipilih; ketiga, Anggota Kepolisian Negara Republik Indonesia dapat menduduki jabatan di luar kepolisian setelah mengundurkan diri atau pensiun dari dinas kepolisian.

Keempat, adalah penetapan kepala daerah terpilih yang didasarkan kepada suara terbanyak. Hal ini tentu saja berdampak pada penyelenggaraan Pilkada hanya akan berlangsung satu putaran (kecuali untuk Provinsi DKI Jakarta yang juga didasarkan pada Undang-Undang Nomor 29 Tahun 2007 Tentang Pemerintah Provinsi Daerah Khusus Ibukota Jakarta Sebagai Ibukota Negara Kesatuan Republik Indonesia) dan tentu saja hal ini akan menghemat biaya penyelenggaraan Pilkada.

Perubahan mendasar yang terjadi dari pelaksanaan Pilkada serentak berdasarkan 
Undang-Undang Nomor 1 tahun 2015 Jo. Undang-Undang Nomor 8 tahun 2015 dikaitkan dengan implementasi di lapangan dan implikasinya, setelah menelaah lebih jauh isi substansi dari Undang-Undang Nomor 32 Tahun 2004,
Undang-Undang Nomor 1 tahun $2015 \mathrm{Jo}$. Undang-Undang Nomor 8 tahun 2015 dan Undang-Undang Nomor 10 Tahun 2016, maka perlu merubah ketentuan Pasal 42 ayat (4) dan (5) dan (6) sebagai berikut:

\begin{tabular}{|c|c|}
\hline Semula & Menjadi \\
\hline $\begin{array}{l}\text { Pasal } 42 \text { ayat (4) Pendaftaran pasangan } \\
\text { Calon Gubernur dan Calon Wakil } \\
\text { Gubernur oleh Partai Politik } \\
\text { ditandatangani oleh ketua Partai Politik } \\
\text { dan sekretaris Partai Politik tingkat } \\
\text { Provinsi disertai Surat Keputusan } \\
\text { Pengurus Partai Politik tingkat Pusat } \\
\text { tentang Persetujuan atas calon yang } \\
\text { diusulkan oleh Pengurus Partai Politik } \\
\text { tingkat Provinsi. }\end{array}$ & $\begin{array}{l}\text { Pasal } 42 \text { ayat (4) Pendaftaran pasangan } \\
\text { Calon Gubernur dan Calon Wakil } \\
\text { Gubernur oleh Partai Politik } \\
\text { ditandatangani oleh ketua Partai Politik } \\
\text { dan sekretaris Partai Politik tingkat } \\
\text { Provinsi. }\end{array}$ \\
\hline $\begin{array}{l}\text { Pasal } 42 \text { ayat (5) Pendaftaran pasangan } \\
\text { Calon Bupati dan Calon Wakil Bupati } \\
\text { serta pasangan Calon Walikota dan Calon } \\
\text { Wakil Walikota oleh Partai Politik } \\
\text { ditandatangani oleh ketua Partai Politik } \\
\text { dan sekretaris Partai Politik tingkat } \\
\text { kabupaten/kota disertai Surat Keputusan } \\
\text { Pengurus Partai Politik tingkat Pusat } \\
\text { tentang Persetujuan atas calon yang } \\
\text { diusulkan oleh Pengurus Partai Politik } \\
\text { tingkat Provinsi. }\end{array}$ & $\begin{array}{l}\text { Pasal } 42 \text { ayat (5) Pendaftaran pasangan } \\
\text { Calon Bupati dan Calon Wakil Bupati } \\
\text { serta pasangan Calon Walikota dan } \\
\text { Calon Wakil Walikota oleh Partai } \\
\text { Politik ditandatangani oleh ketua Partai } \\
\text { Politik dan sekretaris Partai Politik } \\
\text { tingkat kabupaten/kota. }\end{array}$ \\
\hline $\begin{array}{l}\text { Pasal } 42 \text { ayat (6) Pendaftaran pasangan } \\
\text { Calon Gubernur dan Calon Wakil } \\
\text { Gubernur, pasangan Calon Bupati dan } \\
\text { Calon Wakil Bupati, serta pasangan Calon } \\
\text { Walikota dan Calon Wakil Walikota oleh } \\
\text { gabungan Partai Politik ditandatangani } \\
\text { oleh para ketua Partai Politik dan para } \\
\text { sekretaris Partai Politik di tingkat Provinsi } \\
\text { atau para ketua Partai Politik dan para } \\
\text { sekretaris Partai Politik di tingkat } \\
\text { kabupaten/kota disertai Surat Keputusan } \\
\text { masing-masing Pengurus Partai Politik } \\
\text { tingkat Pusat tentang Persetujuan atas } \\
\text { calon yang diusulkan oleh Pengurus Partai } \\
\text { Politik tingkat provinsi dan/atau Pengurus } \\
\text { Parpol tingkat kabupaten/kota. }\end{array}$ & $\begin{array}{l}\text { Pasal } 42 \text { ayat (6) Pendaftaran pasangan } \\
\text { Calon Gubernur dan Calon Wakil } \\
\text { Gubernur, pasangan Calon Bupati dan } \\
\text { Calon Wakil Bupati, serta pasangan } \\
\text { Calon Walikota dan Calon Wakil } \\
\text { Walikota oleh gabungan Partai Politik } \\
\text { ditandatangani oleh para ketua Partai } \\
\text { Politik dan para sekretaris Partai Politik } \\
\text { di tingkat Provinsi atau para ketua Partai } \\
\text { Politik dan para sekretaris Partai Politik } \\
\text { di tingkat kabupaten/kota. }\end{array}$ \\
\hline
\end{tabular}

Sedangkan perubahan-perbuahan yang mengarah kepada hal negatif terhadap demokrasi di Indonesia, yaitu. Pertama, dihapuskannya persyaratan uji publik. Uji publik dalam perspektif hukum tata negara adalah suatu mekanisme politik 
ketatanegaraan untuk mengetahui, mengukur dan menilai tingkat kompetensi yang meliputi kualitas pengetahuan di bidang pemerintahan dan kepemimpinan, integritas dan moralitas calon kepala pemerintahan yang dilakukan oleh publik (rakyat).Artinya persyaratan uji publik sangat penting untuk proses pencalonan kepala daerah sehingga rakyat tidak sekedar memilih calon yang disodorkan oleh partai politik tetapi juga mengetahui kualitas, integritas, moralitas si calon.

Kedua, adalah fasilitasi KPUD yang dibiayai dari APBD untuk pelaksanaan kampanye debat publik/debat terbuka antarpasangan calon, penyebaran bahan kampanye kepada umum dan pemasangan alat peraga. Hal ini tentunya menambah biaya (cost) yang harus dibiayai oleh negara, padahal sejatinya Pilkada serentak dilaksanakan dalam rangka efisiensi anggaran.

Ketiga, syarat persetujuan pengurus partai politik tingkat pusat tentang persetujuan atas calon yang diusulkan oleh pengurus partai politik tingkat provinsi untuk pendaftaran pasangan calon gubernur dan wakil gubernur, pendaftaran pasangan calon bupati dan wakil bupati serta walikota dan wakil walikota yang diajukan pengurus partai politik tingkat kabupaten/kota Pesyaratan ini tentu saja bisa menghambat demokrasi dan aspirasi di Dewan Pengurus Daerah dan Dewan Pengurus Cabang karena untuk calon kepala daerah diperlukan pesretuuan pengurus di tingkat atasnya yang belum tentu setuju dengan calon yang diajukan oleh DPD Partai Politik untuk Calon Gubernur dan Wakil Gubernur dan DPC Partai Politik Untuk calon Bupati dan Wakil Bupati serta Walikota dan Wakil Walikota.

\section{A. DAMPAK POSITIF DAN NEGATIF PELAKSANAAN PILKADA SERENTAK TANGGAL 9 DESEMBER 2015}

Dampak positif dari pelaksanaan Pilkada serentak 9 Desember 2015 antara lain: Pertama,efisiensi anggaran. Pilkada serentak mampu menghemat anggaran daerah hingga lebih dari 50 persen. Penghematan biaya mencapai lebih dari 50 persen itu karena adanya pemangkasan pada pos-pos anggaran penyelenggara, seperti honorarium bagi Panitia Pemilihan Kecamatan (PPK) dan Panitia Pemungutan Suara (PPS), pos anggaran pengamanan, dan biaya pengiriman logistik pilkada. Selain terjadi penghematan anggaran bagi KPU provinsi, pilkada serentak juga memangkas beberapa pengeluaran KPU kabupaten. Ada bagian-bagian tertentu yang bisa dibagi pembiayaannya antara kabupaten dan provinsi.

Kedua, dampak positif lain dari Pilkada serentak adalah mengurangi kejenuhan masyarakat sekaligus meningkatkan partisipasi mereka. Kejenuhan terjadi ketika dalam waktu yang berdekatan mereka berulang datang ke bilik suara. Ketiga, efek gangguan keamanan yang relatif kecil. Jika pelaksanaan pilkada serentak tingkat provinsi berjalan baik, lalu akan ditingkatkan pada sebagian kabupaten/kota pada tahun 2015, sebagian pada 2018, dan serentak nasional pada 2020. Konflik terjadi pada masa lalu ketika ada pengerahan pemilih dari lain daerah dan menimbulkan kericuhan dari pihak yang merasa dirugikan. Pembahasan Pilkada serentak itu setelah Mahkamah Konstitusi (MK) memutuskan pelaksanaan Pemilihan Legislatif dan Pemilihan Presiden serentak pada 2019. Kekhawatiran bahwa konflik terjadi dan aparat tidak mampu menangani karena ada konflik di wilayah yang bersebelahan terbukti tidak terjadi.

Keempat, Pilkada serentak menjadikan akses rakyat terhadap pemimpin menjadi lebih terbuka karena banyak ruang-ruang dialog dilakukan oleh calon kepala daerah yang dapat mendekatkan rakyat dengan pemimpinnya. Melalui ruang dialog inilah sebenarnya rakyat dapat memanfaatkannya sebagai tempat penyampaian aspirasi rakyat tentang apa-apa saja yang dilakukan oleh calon kepala daerah tersebut jika kelak terpilih sebagai kepala daerah. 


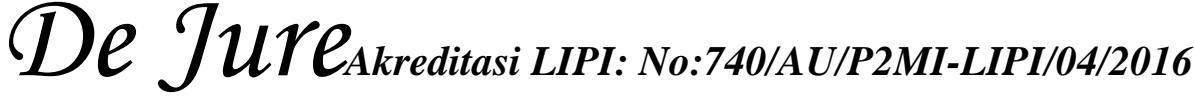

Dampak positif yang belum terasa dari hasil Pilkada Serentak 9 Desember 2015 adalah menyembuhkan penyakit pemerintahan yang terbelah antara pusat dan daerah. Hal ini masih memerlukan proses pemilu serentak yang lebih menyeluruh yaitu serentaknya pemilu nasional dan pemilu lokal. Keadaan konsep divided government, atau pemerintahan terbelah ini antara lain terjadi manakala presiden yang telah dipilih dalam pilpres langsung yang lebih awal berbeda partainya dengan gubernur dan bupati/walikota yang menang namun dari partai yang berbeda hasil Pilkada yang kemudian.

Ini adalah salah satu akibat sistem pemilu yang dipilih oleh negara Indonesia adalah sistem proporsional terbuka, bukan sistem pemilu paralel yang mengharuskan pemilih memilih presiden dan gubernur/bupati/Walikota dari partai yang sama dalam satu paket pilihan partai secara serempak. Maka dari itu sistem pemilu yang ideal untuk pemilu nasional dan lokal yang serentak yang dapat mengatasi penyakit pemerintahan yang terbelah adalah sistem pemilu campuran dengan model paralel.

Selain itu juga terjadi bila eksekutif dikuasai partai politik atau koalisi partai politik yang tidak menguasai legislatif. Peta politik seperti itu membuat pemerintahan tidak berkembang dan terkendala. Sebab, setiap rancangan kebijakan yang diajukan oleh eksekutif di pusat selalu ditentang atau ditolak oleh eksekutif dan legislatif di daerah. Pemerintahan pun lumpuh dan tidak efektif, dan pemilih yang menjadi korbannya karena program tidak bisa berjalan.

Selain dampak positif ada juga beberapa dampak Negatif dari pelaksanaan Pilkada Serentak 9 Desember 2015, antara lain:

Pertama, Jadwal pentahapan yang merupakan kewenangan dari KPU Pusat karena KPU Pusat sebegai pennaggung jawab akhir pelaksanaan Pilkada serentak dan jadwal pentahapan tersebut akan $\begin{array}{llr}\text { digunakan oleh provinsi } & \text { dan } \\ \text { kabupaten/kota } & \text { yang } & \text { akan }\end{array}$ menyelenggarakan Pilkada dengan kondisi penjadwalan yang dibuat oleh KPU Pusat, kesulitan yang dihadapi oleh KPU Provinsi DKI Jakarta yaitu ketika tim dari partai politik mempertanyakan jadwal pendatahan Pilkada dan pihak KPU Provinsi DKI Jakarta belum bisa memberikan kepastian karena jadwal dari KPU Pusat belum turun.

Kedua, Pilkada serentak yang didasarkan pada Undang-Undang Nomor 8 Tahun 2015 yang pembebanan anggarannya dibiayai dari Anggaran Pendapatan Belanja Daerah dikhawatirkan terdapat intrik dari DPRD dan calon petahana serta KPU daerah sebagai pelaksana pilkada di daerah akan disibukkan dengan penyediaan anggaran untuk pelaksanaan Pilkada. Ketiga, adanya upaya penyeragaman situasi yang ada di tingkat lokal. Hal paling signifikan dapat dilihat dari bagaimana proses pencalonan berjalan. Khususnya jika berkaca pada proses pencalonan, maka seharusnya diberikan kesempatan bagi penyelenggara di tingkat daerah untuk melakukan penyesuaian-penyesuaian, sesuai dengan situasi dan kondisi yang ada. Salah satu contoh paling konkrit adalah kewenangan untuk melakukan perubahan terhadap tahapan, program dan jadwal penyelenggaraan bilamana terjadi hal-hal yang tidak diinginkan.

\section{B. MODEL PELAKSANAAN \\ PILKADA SERENTAK YANG \\ IDEAL DALAM UPAYA \\ PENGUATAN DEMOKRASI DI INDONESIA}

Penyelenggaraan pemilu serentak yang mampu melahirkan pemimpin-pemimpin eksekutif maupun anggota legislatif yang amanah sangat diharapkan oleh rakyat Indonesia. Dalam pengertian pemilu legislatif dan presiden yang dibarengkan waktunya? Salah satu versi jawabannya adalah untuk mencegah "pemerintahan yang terbelah" (divided government) yang lazim dipandang sebagai kelemahan sistem 
presidensial ketika presiden dan parlemen dikontrol kekuatan politik yang berbeda. Sistem presidensial yang berkombinasi dengan multi partai, dengan fragmentasi politik dan polarisasi ideologi yang tinggi, berpotensi kelumpuhan akibat kebuntuan eksekutif-legislatif. Akhirnya instabilitas politik terjadi. Pemilu nasional serentak atau pemilu konkuren (concurrent election) diharapkan mampu memunculkan efek konkurensi atau lazim disebut coattail effect sehingga terhindar dari fenomena "pemerintahan yang terbelah". Kendatipun sama-sama serentak, Pemilu konkuren berbeda dengan Pemilu serentak dengan Pemilu sela, dan model Pemilu sinkronis (syncronized election). Di Amerika Latin, jenis Pemilu konkuren dipahami karena coattail effect yang ditimbulkannya. Dibayangkan bahwa kandidat presiden atau sebaliknya partai politik akan saling "menarik kerah" pemilih sehingga pilihan mereka relevan. Efek itu berasumsi tidak mungkin pemilih mencoblos pasangan capres yang diajukan koalisi parpol tertentu, tetapi lantas memilih calon anggota legislatif dari partai di luar koalisi pengusung capres tersebut. Jenis pemilu konkuren lazim diterapkan di beberapa negara Amerika Latin. Pemilu serentak Brasil 2014, misalnya, dilakukan untuk memilih pasangan calon presiden, anggota kongres nasional, gubernur, dan anggota parlemen lokal. Pilpres memberlakukan sistem dua putaran manakala tak ada suara lebih dari 50 persen pada putaran pertama.

Kembali ke Indonesia, Pilkada serentak gelombang pertama yang dilakukan pada Desember 2015 untuk kepala daerah yang masa jabatannya berakhir pada 2015 serta pada semester pertama 2016. Lalu Pilkada serentak gelombang kedua akan dilaksanakan pada Februari 2017 untuk kepala daerah yang masa jabatannya berakhir pada semester kedua 2016 dan kepala daerah yang masa jabatannya berakhir pada 2017. Pilkada serentak gelombang ketiga akan dilaksanakan pada Juni 2018 untuk kepala daerah yang masa jabatannya berakhir pada 2018 dan 2019.
Pilkada serentak gelombang keempat akan dilaksanakan pada 2020 untuk kepala daerah hasil pemilihan Desember 2015. Pilkada serentak gelombang kelima akandilaksanakan pada 2022 untuk kepala daerah hasil pemilihan pada Februari 2017. Pilkada serentak gelombang keenam akan dilaksanakan pada 2023 untuk kepala daerah hasil pemilihan 2018. Kemudian, dilakukan Pilkada serentak secara nasional pada 2027. Jadi mulai 2027, Pilkada dilakukan secara serentak di seluruh provinsi, kabupaten, dan kota di Indonesia, untuk seterusnya dilakukan kembali tiap lima tahun sekali.

Untuk wilayah Indonesia yang terdiri dari 34 Provinsi, 416 Kabupaten dan 98 Kota, pelaksanaan Pemilukada serentak sudah merupakan model yang ideal bila dibandingkan dengan pelaksanaan Pilkada yang lalu. Pada masa Pilkada lalu hampir 3-4 bulan sekali terjadi Pilkada di suatu Kabupaten/Kota, sehingga sangat rawan ditinjau dari segi sosial, politik dan keamanan. Pada masa Pilkada sebelumnya bila salah satu kandidat tidak puas atas hasil pengumuman KPU, maka pendukung kandidat yang kalah dari salah satu partai akan melakukan aksi demonstrasi dan huru-hara. Masa dari partai yang berasalah dari kabupaten tetangga juga akan datang memberi dukungan, sehingga suasana menjadi gaduh dan mencekam. Tetapi dengan pelaksanaan Pemilukada Serentak ini tingkat keamanan menjadi kondusif, karena masing-masing masa dari simpatisan partai juga sedang sama-sama sibuk menyelenggarakan Pemilukada. Seandainya terjadi keributan karena ketidak puasan salah satu peserta di suatu tempat tidak akan merembet ke tempat lain. Dengan demikian, pelaksanaan Pemilukada serentak akan mengurangi gangguan stabilitas keamanan.

Setelah mengkaji dan menelaah beberapa model pelaksanaan Pilkada yang berlangsung di Indonesia, secara ideal Pilkada serentak (Pemilu lokal) dilaksanakan bersamaan dengan pemilihan umum nasional yakni pemilihan Presiden dan anggota DPR, DPD. Pemilu 


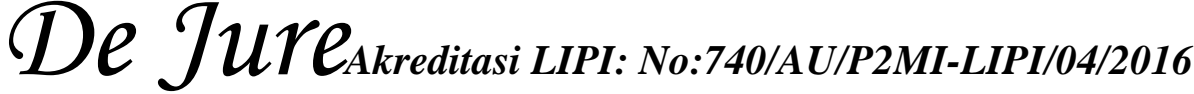

dilaksanakan satu kali dalam lima tahun, untuk semua posisi publik di tingkat nasional hingga kabupaten/kota. Pemilu ini meliputi pemilihan legislatif (DPR, DPD, DPRD Propinsi dan DPRD
Kab/Kota), pemilihan presiden, serta Pemilukada. Untuk jelasnya dideskripsikan dalam gambar di bawah ini:

Gambar Model Pilkada Serentak Sistem Paralel (MMM- mixed member majoritarian)

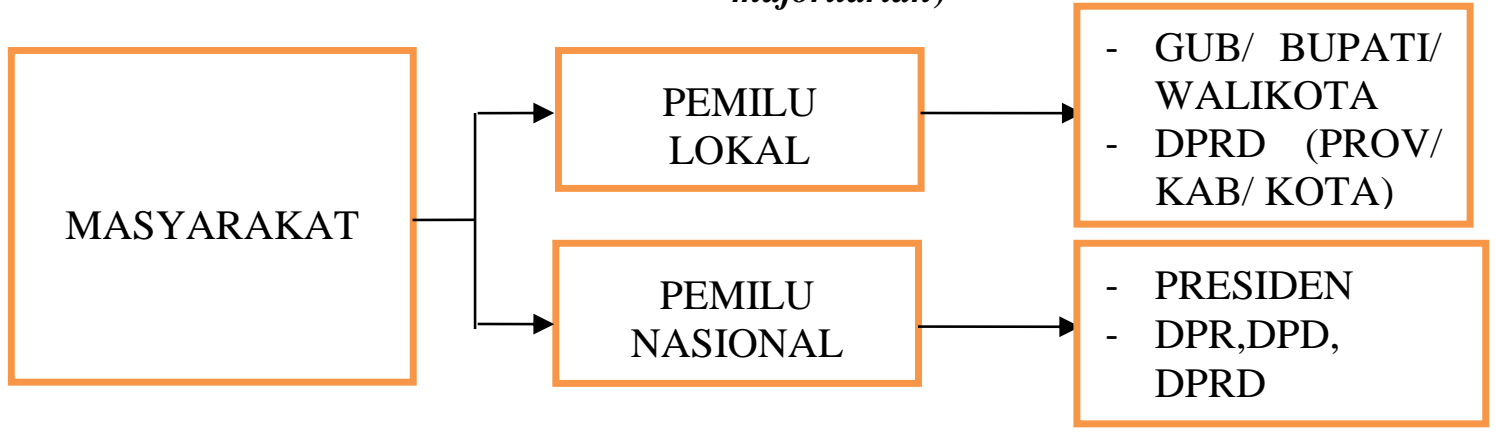

Gambar di atas menunjukkan bahwa masyarakat Indonesia melaksanakan pemilu, baik pemilu lokal maupun Pemilu nasional dilaksanakan secara serentak dalam satu hari. Pemilu lokal yang dilaksanakan untuk memilih Gubernur, Bupati, Walikota maupun anggota DPRD Propinsi, Kabupaten dan Kota. Sedangkan Pemilu Nasional dilaksanakan untuk memilih Presiden, anggota DPR dan DPD. Satu model inilah yang didapat dari penelitian ini, sehingga Pemilihan kepala daerah serentak maupun Pemilu presiden dan wakil dapat berlangsung lebih efektif dan efisien.

\section{KESIMPULAN}

Dari hasil penelitian dapat ditarik kesimpulan sebagai berikut: pertama, 5 (lima) perubahan mendasar pemilihan kepala daerah yang didasarkan pada Undang-Undang Nomor 32 tahun 2004 dengan Pemilihan Kepala Daerah yang didasarkan pada Undang-Undang Nomor 1 Tahun 2015 jo Undang-Undang Nomor 8 Tahun 2015.

Kedua, dampak positif yang terjadi dari pelaksanaan Pilkada serentak, diantaranya: efisiensi anggaran pelaksanaan Pilkada;meningkatkan partisipasi masyarakat dalam Pilkada; efek gangguan keamanan yang relatif kecil; akses rakyat terhadap pemimpin menjadi lebih terbuka. Sedangkan dampak negatif dari pelaksanaan Pilkada serentak, yaitu:dengan Pilkada serentak dikhawatirkan terdapat intrik dari DPRD dan calon petahana serta KPU Daerah sebagai penyelenggara Pilkada dalam penyusunan Anggaran Pendapatan Belanja Daerah; upaya penyeragaman situasi yang ada di tingkat lokal.

Ketiga, model pelaksanaan Pilkada serentak yang ideal dalam upaya penguatan demokrasi di Indonesia adalah Pemilu yang dilaksanakan bersamaan dengan pemilihan umum nasional yakni pemilihan Presiden, anggota DPR dan DPD. Sedangkan Pemilu lokal dilaksanakan untuk memilih Gubernur, Bupati, Walikota maupun anggota DPRD Propinsi, Kabupaten dan Kota.Pemilu dilaksanakan satu kali dalam lima tahun, untuk semua posisi publik di tingkat nasional hingga kabupaten/kota.

\section{SARAN}

Dari hasil penelitian ini diperoleh saran-saran sebagai berikut:

pertama,Komisi II Dewan Perwakilan Rakyat perlu melakukan Perubahan/Revisi Undang-Undang Nomor 10 Tahun 2016 dengan memasukkan substansi sebagai 


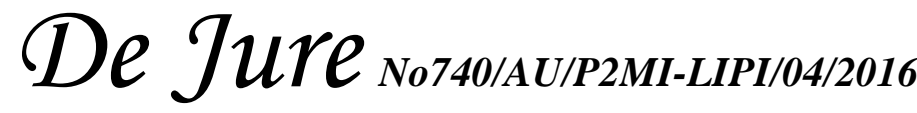

berikut:Warga Negara Indonesia yang dapat menjadi Calon Gubernur dan Calon Wakil Gubernur, Calon Bupati dan Calon Wakil Bupati, serta Calon Walikota dan Calon Wakil Walikota adalah yang memenuhi persyaratan telah mengikuti uji publik yang dilakukan oleh partai politik atau gabungan partai politik pengusungnya.Selain itu, Komisi II DPR RI juga diharapkan untuk merubah ketentuan Pasal 65 ayat (2) yang berbunyi Kampanye sebagaimana dimaksud pada ayat (1) huruf c difasilitasi oleh KPU Provinsi dan KPU Kabupaten/Kota yang didanai APBN; dan merubah ketentuan Pasal 200 menjadi Pendanaan Pemilihan Gubernur dan wakil Gubernur, Pemilihan Bupati dan Wakil Bupati serta Pemilihan Walikota dan Wakil Walikota dibebankan pada Anggaran Pendapatan Belanja Negara.

Kedua, Komisi Pemilihan Umum agar, membuat peraturan mengenai mekanisme uji publik, bahwa Warga Negara Indonesia yang dapat menjadi Calon Gubernur dan Calon Wakil Gubernur, Calon Bupati dan Calon Wakil Bupati, serta Calon Walikota dan Calon WakilWalikota adalah yang memenuhi persyaratan telah mengikuti uji publik yang dilakukan oleh partai politik atau gabungan partai politik pengusungnya. 


\section{De Jure Akreditasi LIPI: No:740/AU/P2MIILIPI/04/2016}

\section{DAFTAR KEPUSTAKAAN}

Amir machmud, Demokrasi, Undang Undang dan Peran Rakyat, dalam PRISMA No. 8 LP3ES, Jakarta, 1984;

Damang Averroes Al-Khawarizmi \& Muh. Nursal NS, Carut Marut Pilkada Serentak 2015, (Jakarta: Philosophia Press, 2016);

Didik Supriyanto, dkk, Menata Ulang Jadwal Pilkada Menuju Pemilu Nasional dan Pemilu Daerah, (Jakarta: Yayasan Perludem, 2013);

F. Budi Hardiman, Demokrasi Deliberatif (Yogyakarta: Kanisius, 2009);

H. Abdul Latief, Hukum dan Peraturan Kebijaksanaan (Beleidsregel) pada Pemerintahan Daerah (Yogyakarta: UII Press, 2005);

Jimly Asshiddiqie, Konstitusi \& Konstitusionalisme Indonesia (Jakarta: Konstitusi Press, 2005);

Koalisi Masyarakat Sipil Untuk Revisi Undang-Undang Pilkada, Menuju Pilkada Serentak Nasional 2012, (Jakarta: Yayasan Perludem, 2015);

Moh. Kusnardi dan Harmaily Ibrahim, Pengantar Hukum Tata Negara Indonesia (Jakarta: PSHTN FH UI dan Sinar Bakti, 1988);

Muhammad Tahir Azhary, Negara Hukum: Suatu Studi tentang PrinsipPrinsipnya Dilihat dari Segi Hukum Islam, Implementasinya pada Periode Negara Madinah dan Masa Kini (Jakarta: Bulan Bintang, 1992);

M. Zaki Mubarak, Demokrasi dan Kediktatoran: Sketsa Pasang Surut Demokrasi di Indonesia, Jurnal Politika: Jurnal Pencerahan Politik Untuk DemokrasiIII, no 3 (Desember 2007);

Tim Peneliti Perludem, Menata Kembali Pengaturan Pilkada, (Jakarta: Kerjasama Perludem, USAID dan Ifes, 2011);

Tjahjo Kumolo, Politik Hukum Pilkada Serentak (Jakarta: Expose, 2015);

Syamsuddin Haris, dkk, Ringkasan Eksekutif Position Paper, Pemilu Nasional Serentak 2019, (Jakarta :
Elektoral Research Institute, Pusat Penelitian Politik LIPI dan The Australian Electoral Commission (AEC), 2015).

\section{PERATURAN \\ UNDANGAN}

PERUNDANG-

Undang-Undang Nomor 32 Tahun 2004 tentang Pemerintahan Daerah;

Undang-Undang Nomor 1 Tahun 2015 tentang Penetapan Peraturan Pemerintah Pengganti Undang-Undang Nomor 1 Tahun 2014 tentang Pemilihan Gubernur, Bupati, dan Walikota menjadi Undang-Undang;

Undang-Undang Nomor 8 Tahun 2015 tentang Perubahan Atas UndangUndang Nomor

1 Tahun 2015 tentang Penetapan Peraturan Pemerintah Pengganti Undang-Undang Nomor 1 Tahun 2014 tentang Pemilihan Gubernur, Bupati, dan Walikota menjadi Undang-Undang;

Undang-Undang Nomor 10 Tahun 2016 tentang Perubahan Kedua atas UndangUndang Nomor 1 Tahun 2015 tentang Penetapan Peraturan Pemerintah Pengganti Undang-Undang Nomor 1 Tahun 2014 tentang Pemilihan Gubernur, Bupati, dan Walikota menjadi Undang-Undang;

Peraturan Pemerintah Pengganti Undang Undang Nomor 1 Tahun 2014 tentang Pemilihan Gubernur, Bupati, dan Walikota. 